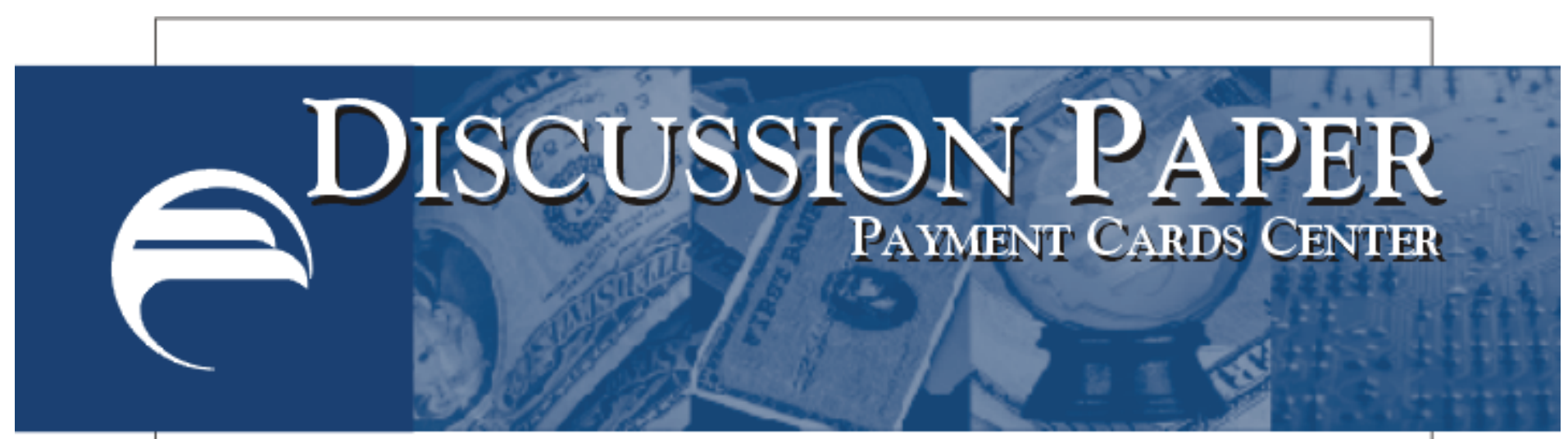

\title{
Mandatory Arbitration Clauses in the Credit Card Industry*
}

\author{
Mark Furletti
}

January 2003

Summary: On September 26, 2002, the Payment Cards Center of the Federal Reserve Bank of Philadelphia held a workshop that explored the use of mandatory arbitration clauses in credit card agreements between issuers and consumers. Leading the workshop was Alan S. Kaplinsky, chair of the Consumer Financial Services Group at Ballard Spahr Andrews \& Ingersoll, LLP. A pioneer in the development of consumer arbitration clauses, Kaplinsky described the arbitration process as a conflict resolution mechanism in the payment cards industry. He also provided a contextual overview of the Federal Arbitration Act of 1925, subsequent legislative actions, and relevant court cases. This paper summarizes his presentation and the ensuing discussion with workshop participants.

* The views expressed here are not necessarily those of this Reserve Bank or of the Federal Reserve System.

\section{Federal Reserve Bank of PhiladelPhia}




\section{Introduction}

Over the past five years, credit card issuers have attempted to stem expensive class action litigation by introducing arbitration clauses into their contracts with cardholders. While seen by many as an efficient tool for resolving conflicts between consumers and issuers, the arbitration process itself has become the source of much litigation. In June 2002, the American Banker, in a special report on legal trends in banking, noted that "many of the cases drawing the attention of banking lawyers [today] involve the enforceability of arbitration clauses." With several high profile cases still pending, the future of arbitration as a permanent part of credit card issuers' agreements with cardholders remains uncertain. Motivated by the widespread adoption of arbitration by the card industry, the Center invited Alan S. Kaplinsky, chair of the Consumer Financial Services Group at Ballard Spahr Andrews \& Ingersoll, LLP to lead a workshop discussion on this subject. This paper summarizes his presentation and highlights some of the ensuing discussion with workshop participants.

\section{The Evolution of Arbitration in the U.S.}

One of the well-established roles that U.S. courts play is that of settling disputes. When a disagreement arises between two parties, courts are often asked to examine relevant statutes and common law to settle the dispute. This process, however, can be resource intensive. Often, both parties must hire attorneys, appear before the court, engage in extensive discovery (i.e., a compulsory disclosure of facts and documents), adhere to a court-determined timeline, and explain highly technical processes and products to an unfamiliar judge or jury. In this way, litigation can be expensive and slow.

Arbitration is a response to these shortcomings and is deemed to be a less-expensive, more efficient alternative to a court dispute resolution. When two parties agree to arbitrate, they agree to ask an impartial third party, or "neutral," to review their case and resolve their dispute. The two parties can enter into an agreement to arbitrate before or after a dispute arises. If 
arbitration is agreed to before a dispute arises, it can be part of the broader contract into which the two parties enter. Once a part of the contract, the arbitration provision becomes as enforceable as any other contractual provision.

Arbitration is not a new method of resolving conflicts. President George Washington offered a very good explanation of how it can, and in many cases does, work. In his last will and testament, written on July 9, 1799, Washington dictated that:

All disputes [arising from his will] shall be decided by three impartial and intelligent men, known for their probity and good understanding; two to be chosen by the disputants, each having the choice of one, and the third by those two — which three men thus chosen, shall...declare their sense of the testator's intention; and such decision is, to all intents and purposes to be as binding on the parties as if it had been given in the Supreme Court of the United States.

It was not until Congress enacted the Federal Arbitration Act (FAA) in 1925, however, that arbitration became a widely used method of resolving disputes. Until that point, courts did not always look favorably upon arbitration because it effectively transferred power away from the court and into the hands of nonpublic entities. After the passage of the act, arbitration became a favored dispute resolution method of many businesses. It was particularly favored by those in the labor, securities, international trade, maritime, and construction industries.

The fundamental premise of the Federal Arbitration Act, Kaplinsky explained, is that parties can agree by contract to arbitrate their claims before or after a dispute arises. The act gives such arbitration agreements the same effect as any other part of a contract. In this way, these agreements can be invalidated only by a legal theory that can be used to invalidate any other type of contract (e.g., lack of capacity to enter into a contract, duress, lack of consideration, unconscionability, etc.). Arbitration can be invoked by a "motion to compel arbitration" in a case 
already in court or by a separate lawsuit seeking to enforce arbitration in the state where arbitration is to be held. When such a motion or suit arises, the court must limit the scope of its decision to the applicability and validity of the arbitration agreement and maintain a heavy presumption in favor of enforcing it. The FAA also restricts the right of parties to appeal arbiters' decisions, allowing such appeals only in the case of arbiter bias, misconduct, or manifest disregard of the law.

For several decades after the enactment of the FAA, arbitration was not often used in contracts between consumers and businesses. This changed, however, in the mid-1990s. During his presentation, Alan Kaplinsky explained that two Supreme Court cases (Allied-Bruce Terminex v. Dobson in 1995 and Doctor's Associates v. Casarotto in 1996) federalized the law of arbitration and held that the FAA was binding in state courts. These two rulings, along with a legal environment that banks perceived as increasingly hostile, helped to spur the adoption of arbitration by banks and finance companies that issued credit cards.

\section{The Adoption of Arbitration by the Credit Card Industry}

Kaplinsky explained that in the years immediately preceding industry-wide adoption of arbitration clauses, there were significant increases in the volume and complexity of litigation filed against issuers. Card issuers claimed that an intricate web of evolving federal, state, and local laws made it difficult and expensive for them to avoid a disclosure or processing misstep. Issuers were also alarmed by an increasingly active plaintiffs' bar, hostile state courts and judges, and costly settlements that made issuers attractive targets for threatened litigation. Above all, Kaplinsky stated, issuers that perceived themselves as making a good faith effort to adhere to the rules were finding that their exposure to lawsuit risk was completely unpredictable.

In response to these perceived risks, Kaplinsky noted that card issuers introduced mandatory arbitration clauses into their contracts with cardholders. Issuers saw arbitration as a way of gaining control over legal budgets and represented a less expensive, more predictable, 
faster, and uniform way of settling cardholder disputes. By limiting consumers' rights of appeal, prohibiting the formation of classes, and restricting discovery, arbitration significantly curtailed the amount of time and money issuers needed to allocate to its customers' legal claims.

Arbitration agreements, Kaplinsky explained, can cover a broad range of claims, including those that issuers most often face. Claim types that lend themselves to arbitration include:

- Breach of contract;

- Common law wrongs (e.g., fraud);

- Truth in Lending Act (Regulation Z) violations;

- Fair Credit Billing Act violations;

- Fair Debt Collection Practices Act violations; and

- Equal Credit Opportunity Act violations.

Arbitration can also be used to seek injunctive relief and can have retroactive application to claims that predate the effective date of the arbitration agreement.

While the cost savings of mandatory arbitration can be substantial, Kaplinsky said that the method has some drawbacks for issuers. Unlike decisions made by judges, decisions made by arbiters are not public and do not create a legal precedent for future claims. In this way, neither issuers nor potential claimants can rely on an arbiter's decision in a previous case to influence an arbiter's decision in a pending case. In addition, arbitration clauses can be expensive for issuers to implement, and the clause can often provoke litigation over enforceability. Finally, some courts (e.g., those in California) have permitted arbitration to proceed as a class action — one of the major actions that the clauses were intended to avert.

Despite these drawbacks, the benefits of arbitration have been sufficient to induce almost every major credit card issuer in the U S. to adopt mandatory arbitration clauses for their new and existing customers. Several early adopters introduced mandatory arbitration clauses into their cardholder agreements in the late 1990s, with most others following in the last few years. Since 
that time, Kaplinsky noted, the clauses have been accepted in most courts, been seen by many observers as a fair and effective tool for resolving consumer claims, and have served to control issuers' legal expenses. At the same time, however, those that oppose the clauses have criticized arbitration as a less-than-fair way of resolving consumers' claims.

\section{Attacks on Arbitration}

Since the adoption of arbitration clauses by credit card issuers a few years ago, consumer advocates, attorneys, and legislators have argued that the application of arbitration to resolving consumer credit disputes is inherently unfair. Kaplinsky summarized some of the key arguments that opponents often assert:

- The clauses lack mutuality, since a few issuers allow themselves to seek redress in court for collections purposes but do not extend the same privilege to consumers;

- The clauses are "unconscionable" in that arbitration fees are higher than court fees, arbiters are biased toward issuers, arbitration procedures, including the limited right to conduct discovery and the general inability to prosecute class actions, hurt consumers, and/or arbitration forums are inconvenient;

- The clauses violate a consumer's right to a jury trial;

- The clauses violate a federal or state statute that either authorizes a consumer to go to court or to bring a class action; and

- The clauses are part of "take-it-or-leave-it" contracts (i.e., contracts of adhesion) of which consumers are not aware.

Kaplinsky said that he advises issuers who are drafting arbitration clauses to consider these issues and urges them to adopt a "fair" clause. A "fair" clause, in Kaplinsky's opinion, complies with the consumer due process protocols adopted by the major providers of arbitration services, allows both parties to invoke arbitration, has an exception for claims that can be made in 
small claims court, may offer to pay the difference between court and arbitration fees, and considers requests from indigent consumers to pay the costs of arbitration.

Responding to allegations about overall fairness, Kaplinsky believes that empirical data will ultimately show that consumers do well in arbitration. He noted, however, that there is limited experience on which to base an analysis, since many of the major issuers did not adopt the clauses until recently. Nevertheless, he expects that in the next few years sufficient data will be available to conduct an impartial study of arbitration outcomes. On the basis of his own experience with a number of major issuers, Kaplinsky believes that the data will show that consumers prevail more often when they arbitrate their claims than when they go to court. To further substantiate this statement, he cited anecdotal evidence that suggests that in many cases arbiters will "split the baby" and provide some relief to a consumer even when, by strict legal standards, he or she may not have a valid claim.

\section{Arbitration and Banking Regulation}

During the discussion Kaplinsky addressed the fairness and appropriateness of arbitration in the banking environment by noting the role of government regulators. He asserted that arbitration is ideally suited for retail banking-related claims because federal agencies can essentially play the role that private attorneys general play in unregulated industries — that of deterring bad corporate conduct. He noted that government regulators have an advantage over attorneys who are representing a class in that they can more efficiently investigate and prosecute bad conduct of credit card lenders. Regulators are not constrained by the court's evidentiary processes, have better access to information through their involvement in the examination process, and are able to set priorities based on relative importance rather than the prospect of maximizing attorney's fees. In addition, regulators have other tools (e.g., guidance memos) to address systemic problems and effect changes without attracting lots of publicity. 
Kaplinsky cited the $\$ 300$ million settlement agreement that Providian reached with the Office of the Comptroller of the Currency in 2000 as a good example of how regulatory action can be preferable to class action lawsuits from a social welfare perspective. In that settlement, Providian agreed to enhance its disclosures, modify its marketing practices, and compensate customers who had been wronged. When consumer claims are settled in a class action, Kaplinsky explained, the result is often very different. First, less money is paid to those who experienced the loss because of the need to pay lawyers' fees. These fees can range from 25 to 50 percent of the amount awarded. Second, plaintiffs' attorneys may not insist to the same extent as government regulators that there be ongoing corrective actions. Finally, it generally takes much longer to resolve the dispute.

Kaplinsky also pointed out that federal banking agencies have the authority under section 8(b) of the Federal Deposit Insurance Act and section 5 of the Federal Trade Commission Act to investigate unfair or deceptive practices. With the power to resolve consumer complaints and target bank examinations based on unfair or deceptive conduct, federal agencies are in a better position than a certified class and its counsel to seek redress. Federal Reserve Chairman Alan Greenspan, in a recent letter to Representative John LaFalce, addressed the effectiveness of this authority under the FTC Act. He wrote, "Enforcement orders and agreements must be made public, and as a result would curtail similar unfair or deceptive practices by other banks." Kaplinsky believes that disincentives, such as enforcement orders and regulatory actions, are significant factors in further protecting consumer interests.

Critics of arbitration also contend that class action lawsuits help deter issuers from committing an act that has a very small injurious effect on many people. For example, the costs of individually arbitrating a wrongfully charged \$29 late fee far exceed any damages that could likely be awarded to an offended consumer. If forced to choose between paying the fee and arbitrating, consumers would likely choose the former. A class action, however, bringing together thousands of such claims, would be more appropriate from a cost and efficiency perspective. In 
cases like this, critics argue, it is only through a class action, and not through individual arbitration, that a just outcome can be achieved.

Kaplinsky's response to these critics is that individual cardholders with such small claims should either assert them in arbitration where the card issuer will likely pay all arbitration fees or in small claims court, or file a complaint with the appropriate federal banking agency.

Critics' arguments, Kaplinsky indicated, underscore the need for regulatory oversight and examination to identify and curtail any such wrongs. In the discussion, however, it was noted that the current trend in banking supervision is toward a risk-based examination approach. Examiners are doing less transaction-level auditing, in which they might more readily catch such irregularities, and are focusing their efforts on practices that represent the most risk to a bank's safety and soundness.

During the discussion it was noted that, in addition to a review of reported data on consumer complaints, a review of arbitration proceedings and cases might be helpful in identifying recurring violations. Kaplinsky explained that this is not currently possible. He noted that neither the records of arbitration proceedings nor aggregated data about the types of claims being brought to arbitration are public information. It may be possible, however, in the future to obtain aggregate information.

\section{Conclusion}

Overall, arbitration reduces the costs of resolving disputes for card issuers by eliminating class action lawsuits and unpredictable jury awards. In Kaplinsky's view, this lowers the cost of credit for consumers and returns more dollars to those who are wronged. These benefits will be realized and the system will be fair, he concluded, as long as federal banking agencies remain vigilant and exercise the enforcement powers granted to them by Congress.

Nevertheless, the use of arbitration in consumers' credit card agreements continues to be challenged. The plaintiffs' bar represents one level of vocal opposition, and there is a growing list 
of state courts that are challenging the clauses. If arbitration is to remain a viable conflict resolution alternative to litigation in the credit card industry, it will be incumbent on card issuers to address arbitration's fairness and on regulators to provide appropriate oversight of issuers' practices. In addition, an empirical analysis of arbitration decisions would serve to diffuse much of the subjectivity that currently surrounds the debate. 